\title{
Banking Development In The Former Yugoslavian Republics
}

Jelena Radzic, Ryerson University, Canada

Ayse Yuce, Ryerson University, Canada

\begin{abstract}
This paper analyzes the development of the banking sectors in six former Yugoslavian Republics. Slovenia, Croatia, Bosnia and Herzegovina, Serbia and Montenegro formed their own banking system in the last decade. Some of them faced with banking crisis, the others had experienced smoother transition. We examine the challenges faced by these countries with respect to European Union membership.
\end{abstract}

\section{INTRODUCTION}

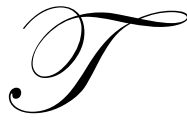

he Socialist Federal Republic of Yugoslavia (SFRY) had an important international role in the economic and political fields, from which all its republics (Slovenia, Croatia, Macedonia, Bosnia and Herzegovina, Serbia and Montenegro) benefited. The country introduced a worker self-management system in 1971, and the greater power of each republic was established in 1974. Its banking market differed from other planned economies. Banks participated in commercial as well as financial activities for enterprises. The National Bank of Yugoslavia (NBY) used a credit ceiling and special interest rate for some areas of the economy.

The banking market in the Socialist Federal Republic of Yugoslavia (SFRY) from 1960 to 1980 was one of the most advanced at the time in Central and Eastern Europe. This banking market, which had a social context, introduced a two-tier banking system in 1960, signifying the early start of market-oriented reforms. At the end of the 1980s, the SFRY was the most developed country in the region as well as the largest, with the highest population. All the republics had a great base for developing a strong and healthy banking structure. In 1985 there were 170 banks, and from the 1970s to the 1980s there was no bank liquidation or bankruptcy.

The SFRY experienced several crises during the 1980s, caused by a high exchange rate, a high fiscal deficit, and low performance in trade, which was further exacerbated due to a big recession and international crises. Dinar, the national currency, depreciated, and in that time it was hard to repay foreign loans, which had been obtained in 1970s and 1980s with the support of the government. It had a negative impact on the portfolio of the banks and the country's growing debt. The debt was postponed by reaching an agreement with the Paris and London Club. Reforms that were aimed at solving the crises failed, which resulted in a new banking law in 1989. Also, in order to provide economic stabilization more quickly, the government started the Markovic anti-inflation program in 1990, which allowed private or mixed firms to be established. A year later, all those reforms were interrupted by the collapse of the Yugoslavian federation.

The banking reforms in 1990s started later than in most Central and Eastern European countries. The main reason for the delay was the break-up of the Yugoslav federation in 1991 with the separation of Slovenia, which was followed by a small military conflict and then a much larger conflict that turned into war in Croatia (1991-1992) and in Bosnia and Herzegovina (1992-1995). Those military conflicts as well as hyperinflation, high unemployment rates, and many other reasons resulted in a slowdown of economic as well as political reforms. From its favorable position in the region, the situation dramatically changed for all the former republics of the country, destroying all the advantages it once had. 
The main purpose of this paper is to explain and compare banking development in the former Yugoslavian republics, which was driven by fiscal sector reforms. The banking sector has been growing rapidly over the last decade and there are many factors that are predicting positive banking developments in those countries. But besides the positive outlook, there are still major challenges that many of the countries will face.

The paper is organized in the following manner: next section covers the previous studies on Central and Eastern European country banking sector. Methodology and data are presented in section three. While section four focuses on each country's banking development from 1990s to 2005, which will include: the size and the structure of the banking sector, the loan and deposit portfolio, the profitability of the banking sector and regulatory activities, section five examines cross-country comparison. We conclude the paper with discussion in section six.

\section{PREVIOUS STUDIES}

Some studies have examined the performance of domestic and foreign banks by comparing them and by analyzing their efficiency and profitability based on pooled data (Bonin, Hasan, \& Wachtel, 2005; Havrylchyk \& Jurzyk, 2006). Bonin, Hasan, and Wachtel (2005) examined foreign-owned bank efficiency in eleven countries in transition, and concluded that those banks provided better service and were more cost-efficient. Also, banks that are government-owned are less efficient and provide less service than privatized banks. Havrylchyk and Jurzyk (2006) analyze profitability in domestic and foreign banks in Central and Eastern Europe based on 256 banks from 19952003. Better performance is achieved by greenfield banks compared to takeover and domestic banks, which show similar results. The main reason for the lower level of ROA in takeover banks is the economic policies of transition countries only allow foreigners to enter their market when the need for new capital arises after a major crisis.

Bonin (2004) studied banking in four southeastern European countries that each showed a different path in terms of privatization: Slovenia, Croatia, Bulgaria, and Romania. Croatia and Bulgaria started strongly, selling banks to foreigners. Slovenia had a different approach by trying to avoid the sale of major banks to foreigners and instead concentrated on creating strong domestic banks, while Romania sold half of its assets to foreigners and the other half belonged to the state. Slovenia showed the best performance of the four in terms of financial debt, business lending, and deposit collection. Both of the former Yugoslavian republics reveal that the market is overbanked. Also, Bonin (2004) concluded that in order to have an efficient financial intermediation, foreign ownership is not necessary. Gomel (2002) conducted a study on the transitions of the financial as well as banking sectors in countries in southeastern Europe. Crises developed due to political instability, which was followed by economic instability. In order to resolve the banking crisis, the operational, institutional, and financial elements have to be considered along with the support from the government. Kraft (2004) conducted an examination of the challenges and accomplishments in banking reforms in southeastern Europe. The challenges that the countries face are: a poor legal framework, an undeveloped security market, as well as a non-bank financial institution. The entry of foreign banks will bring up the concentration and create a lot of challenges for banking supervision. But in addition to all the challenges, there are also huge benefits that result from the entry of foreign banks: an increase in stability and improvements in the banking sector, new products and services, greater capital, and consolidation of this sector. Wisniwski (2003) looked at bankers' perspectives with regard to the countries of southeastern Europe to conclude that due to the increase in competition, small banks will merge causing greater levels of concentration in the future, and the banking sector will offer more diversity in terms of its product.

\section{METHODOLOGY AND DATA}

This research paper will examine the development of the banking sector in one country (SFRY), which had a leading role during the $60 \mathrm{~s}$, and separated into six countries with different central banks and their currencies.

The development of the banking sector in these countries is different. The variations were mainly caused by variations in economic transition as well as the differences that existed in the Yugoslavian federation, which were caused by the different levels of economic importance of each country. In order to take a closer look at the banking development of those countries, this research paper will use a cross-country comparison methodology and examine the following aspects: 
- Size and structure of the banking sector - The paper will examine the number of banks in each country, whether or not the number of banks declined or increased from 1990 to the present, and the reason for the change.

- Loan and deposit portfolio - The paper will closely examine development of these portfolios as well as the current structure. Special attention will be given to the poor quality of credit portfolio, which was a major problem during the 1990s for all the countries. There will be an analysis of banks' supervision methods.

Profitability of the banking sector and regulatory activities - The paper will discuss important ratios such as gains/losses, return on assets (ROA) and return on equity (ROE). Financial intermediation, total assets as a percentage of the GDP, will be examined in relation to each country. Closer look will be on minimum capital adequacy ratio and minimum capital requirement.

This paper will cover different periods, starting with the independence of each country (Slovenia, Croatia, and Macedonia in 1991; Bosnia and Herzegovina in 1992; Serbia's reforms from the mid-1990s; Montenegro's monetary independence in 2000) to 2004/2005 depending on the available data. After taking a closer look at each banking market, part of this paper will make a cross-comparison of the banking markets of those countries by analyzing reforms in each country, their economic performance in 2005 as well as some main banking indicators such as concentration of banking system, ownership structure, non performing loans, profitability and financial intermediation.

Data are collected from the central banks, their annual reports, the International Monetary Fund, World Bank, European Bank for Reconstruction and Development (EBRD) and the wiiw Database incorporating national statistics.

\section{BANKING DEVELOPMENT AFTER THE COLLAPSE OF THE SFRY}

In Slovenia the Bank Rehabilitation Agency (BRA) was established in 1991 to assist the rehabilitation process of banks. This banking sector during 1990s did not suffer crises. The two largest banks were put into the rehabilitation process in 1993, and one more bank followed in 1994. Those three banks counted for half of the banking sector and finished successfully their rehabilitation by 1997, showing positive results such as a great decrease in non-performing loans, increase in profits, and significant organizational and institutional improvements. In 2001, the program of privatization was adopted by the government of Slovenia for two state-owned banks, Nova Ljubljanka Banka (NLB) and Nova Kreditna Banka Maribor (NKBM). The program included the sale of $48 \%$ shares of NLB capital, by leaving the government to own 25\%, while for NKBM plan was to sell $65 \%$ shares.

Banking developments in Croatia during 1990s experienced highs and lows, and can be divided into two periods: the first was linear rehabilitation and the rehabilitation of four banks in 1996; and the second one was the large banking crisis of 1998. The first period, linear rehabilitation, started in 1991 and included the "big bonds" that were issued in response to problems with bank insolvency as well as bonds for old currency savings accounts. Those measures did not change banking operations, and due to insufficient results, the rehabilitation process started in 1996 (Splitska Banka, Rijecka Banka, Privredna Banka, and Slavonska Banka). Their rehabilitation process went through several phases and Slavonska Banka was the first bank of the four that completed a process of rehabilitation as a private bank. After clearing their balance sheets, the lending rates went down that resulted in a recession that began with the Dubrovacka bank crisis, which was the fifth largest bank, on March 1998. Five months later, a similar crisis occurred, this time with one more bank - the sixth largest one. During that period, Croatia was one of the countries that reached the highest fiscal expenditure in the world, measured at 31\% of the GDP. In late 1999 and at the beginning of 2000, the situation improved and the account deficit was measured at $2.1 \%$ of the GDP.

Reconstruction of the Macedonian banking sector started relatively late, in 1995, by creating the Act on Rehabilitation and Restructuring that focused on financial restructuring and included the writing of old foreign exchange deposits, claims and liabilities regarding foreign credits, and reconstruction of the biggest Macedonian bank, Stopanska Banka. The cost of rehabilitating the banking sector was one of the most expensive in the world, reaching $42.3 \%$ of GDP at the end of 1995 . This amount increased to 45.8\% of GDP in 1999 after recapitalization of Stopanska Banka. 
Signing the Dayton Peace Accord in December 1995, Bosnia and Herzegovina (BiH) was divided into two entities: the Federation of Bosnia and Herzegovina (FBiH) and the Republika Srpska (RS). Those entities had authority over banking privatization and supervision of the banks. Each entity implemented its own reforms, starting in 1997 in FBiH and 1998 in RS, showing faster development in FBiH than in RS. One of the first steps in banking development was the establishment of banking agencies in each entity, in FBiH at the end of 1996 while in RS during 1998, whose main function is to issue and revoke licenses to banks and to supervise them.

Reconstruction of the Serbian banking system started relatively later than in other republics. Main reason was unresolved situation with Montenegro, which was not immune to sensitive territorial issues, which held back the development of the banking sector. In early 2002, Serbian authorities decided to liquidate the four largest banks (Jugobanka, Beobanka, Beogradska banka, and Investbanka) primarily because losses were much higher than predicted, there was no positive outlook for the next couple of years, there was a high decrement in deposits, and people had no confidence in the banks and their activities. This was a crucial move that had to be done and those four largest banks represented 57\% of the total assets, with the liquidation cost at around 1\% of the GDP or around USD 90 million.

Comparing the smallest republic of former Yugoslavia, Montenegro, to other republics that gained their independence in early 1990s, we can see that Montenegro started its move towards monetary independence back in the late 1990s with the introduction of the Deutsche Mark (DM) in November 1999. It was meant to reduce Serbia's political influence. Between January 2002 and March 2002, the DM was replaced with the euro, and today it represents an instrument of payment. With establishment of the Central Bank of Montenegro (CBM) which started to operate on March 15, 2001 we can say that banking reforms in Montenegro began in 2001 with reorganization of Montenegrobanka, which was a leader bank at that time.

Next we will examine the size and the structure of banking sector in each country.

\section{Size And Structure Of The Banking Sector}

In 1997 the Slovenian banking sector had 28 banks, 6 savings banks and 70 savings cooperatives, having their share in total assets at $98 \%, 0.4 \%$ and $1.6 \%$, respectively. That year, there were no new bank licenses issued and no mergers happened, but the first banking groups were established. A banking group represents the number of banks in which one bank has, directly or indirectly, $40 \%$ of the shares or more of capital in other banks from a group and controls it. In Slovenia, four banking groups emerged: Banka Celje Banking Group, Nova Ljubljanska Banka Banking Group, SKB Banking Group and Banka Koper Banking Group. By 1998, only two banking groups were left, and this number was reduced to one banking group, Nova Ljubljanska Banka, in 1999. That same year, Hypo Alpe Adria Banka d.d. Ljubljana was established, representing the new bank on this market in the last five years. The number of banks continued to decrease, reaching 19 by the end of 2005; there were three savings banks and three foreign bank branches on this market. Participation of foreigners in capital increased by $2.7 \%$ due to the establishment of a new bank in Slovenia named BAWAG Banka, and also due to an increase of capital from foreigners in Abanka Vipa. The shares that were owned by the Republic of Slovenia decreased to $18.1 \%$ in 2005 from $19 \%$ in 2004.

The banking sector in Slovenia is over-banked, and the concentration is still high, with the three largest banks having 50.4\% in total assets. In December 2005, the largest Slovenian bank was NLB, with 31.5\% of the market share in total assets, and NKBM, which is state-majority-owned, took second place with $10.3 \%$ shares.

During 1998 in the Croatian banking system there were 60 banks and 36 savings banks, having their share in total assets at $98.5 \%$ and $1.5 \%$ respectively. At that time, most of the banks were private. However, the four largest banks in this market were government-owned and made $34.1 \%$ of the total assets. The banking system was very concentrated at 53\%, which is lower than two years ago when the ratio was at 59.9\%. The decrease in the number of banks was caused mainly by the bankruptcy proceedings of seven banks in 1999 and four in 2000, as well as by the mergers of four banks. The following changes occurred in the banking sector in 2000s: the number of banks continued to decrease, reaching 34 by the end of 2005; savings banks almost disappeared. The change in the 
ownership structure of banks meant they were now in favor of foreign ownership, which reached $91.3 \%$ at the end of 2005 .

The banking sector is over-banked and the concentration is still relatively high with three of the most powerful banks having $54.14 \%$ of the shares in total assets. Concentration is expected to increase due to mergers that will take place in the near future, keeping in mind the existence of 27 small banks. In December 2005, the largest Croatian bank was Zagrebacka Bank with $24.33 \%$ of the market share in total assets, and Privredna Banka took second place, while the next four places were taken by Austrian banks.

The Macedonian banking sector in 1999 had 23 banks, 16 saving houses and 1 foreign representative office. The following year, 2000, can be marked as the turn-around year for this market, in which privatization continued and reached a level of $83.5 \%$. Foreign investment in this year increased to $40.8 \%$ from $19.3 \%$ in the previous year, mainly because of the investment of 133 million Deutsche Mark (DM) in Stopanska Banka by three foreign banks (National Bank of Greece, European Bank for Reconstruction and Development (EBRD) and the International Financial Corporation). From 2001-2004, the number of banks in Macedonia stayed at 21. At the end of 2005, the banking sector in Macedonia was made of 20 banks and 14 savings houses. This banking market was over-banked, and the largest Macedonian bank was Komercijalna Banka, with 26.3\% of market share in total assets. The concentration of the three largest banks was high, with $67.73 \%$, and this ratio is expected to increase in the near future by the merging of smaller banks. Foreign banks, mainly from the surrounding region, played an important role in this banking market. In 2000 the major inflow of foreign capital took place and their share of total capital was 49.1\% in December 2005. The shares that were owned by the Republic of Macedonia were $4.5 \%$, while private domestic ownership was $46.4 \%$ of total capital.

During 1996, the banking system in $\boldsymbol{B i H}$ had 53 banks mainly privately-owned. Their main purpose was to offer international transfers, and they controlled a very small portion of the total assets. There were 23 banks out of 53 banks, 15 in $\mathrm{FBiH}$ and 8 in RS, that were state-owned and controlling $80 \%$ of total assets. Although foreigners had the same regulations as domestic banks, in March 1997, Turkish Ziraat Bank was the first foreign bank founded with foreign capital in BiH. The following year's consolidation in the banking sector continued, and in 2002, the number of banks fell to 40. Taking a closer look at each entity, decrease in the number of banks was evident in $\mathrm{FBiH}$, where the number was reduced from 44 banks in 1999 to 29 banks in 2002. On the other hand, banking market in RS was much smaller, made of 11 banks at the end of 2002. A further decrease in banks was measured through 2004 (by 3 banks in $\mathrm{FBiH}$ and by 1 in RS), mainly due to the merging of banks and revoking banking licenses in two banks. The state ownership structure in FBiH increased from 12.6\% in 2003 to $17.8 \%$, caused by an increase in the capital of the government in Investiciska Banka. At the end of 2005, the banking sector of BiH was made of 33 banks, and comparing it to the previous year shows no change in the number of banks while the ownership structure changed in several banks. Five banks from FBiH were under temporary management. The ownership structure in $\mathrm{FBiH}$ at the end of 2005 was in favor of foreign ownership, which reached $70.2 \%$ at the end of 2005 ; shares of state capital were at $16.9 \%$ while shares of domestic private capital were at $12.9 \%$.

The banking system in $\mathrm{FBiH}$ was highly concentrated, with three banks making $54.86 \%$ of total assets, while this ratio in RS was much higher at $85.18 \%$. The largest bank in FBiH was Raiffeisen Banka BiH dd Sarajevo, with $21 \%$ of market share in total assets on December 31,2005, while on the same date, the largest bank in RS was Hypo Alpe-Adria-Bank ad Banja Luka, with 7.44\% share of the total assets.

The Serbian banking sector in 1997 consisted of 106 banks which decreased by almost half to 50 banks in 2002. During 2003 and 2004, the National Bank of Serbia (NBS) did not issue new licenses, but still continued to pursue banking reforms that were mainly focused on the privatization of state-owned banks with no possibility of greenfield investment until the process was finished.

At the end of 2005, the banking sector in Serbia consisted of 40 banks. The banking market was still overbanked. The concentration of the three largest banks was $35.79 \%$ and this ratio is expected to rise in the next few years. Foreign banks play an important role in this banking market, especially Austrian banks and their role is expected to grow faster than domestic banks. The largest bank is the Raiffeisenbank-Austrian bank with $15.56 \%$ of 
the market share in total assets. By examining the changes in the bank ownership structure, it can be seen that the share of banks owned primarily by foreign entities were at $67 \%$ at the end of 2005 . The shares that are owned by the Republic of Serbia were at $23 \%$, but this percent had declined significantly since 2000, while private ownership was at $10 \%$.

The year 2002 can be characterized as a year of key changes in Montenegro's banking system. The number of banks decreased to 10, and it has stayed at that level until today. By fall of 2002, there were two banks in Montenegro in which foreigners had the majority. In 2003 the Central Bank issued a license to Komercialna banka Budva, which was a branch of the bank that had its head office in Belgrade. The number of banks stayed at the same level as the previous year because liquidation started with Ekos Banka based on violations of the law as well as other irregularities. The reorganization of Montenegrobanka was completed successfully, and it was privatized in the second quarter of 2003. The Slovenian bank NLB was a major shareholder of Montenegrobanka with 91.5\%. At the end of 2005, the ownership structure changed drastically with the participation of state decreasing by almost $50 \%$ reaching $13 \%$. Percentage shares of domestic private individuals decreased to $19 \%$ from $36 \%$. Increase of foreign participation in capital was evident and by the end of 2005 as it reached $68 \%$.

At the end of 2005, the banking sector in Montenegro had a high level of market concentration at $66 \%$ based on the total assets of the three largest banks. The largest Montenegrian bank at the time was Crnogorska Komercialna Banka, which was 100\% privately owned. Large banks existed in Montenegro, and it is clear that in the future consolidations and mergers will happen which will cause the market concentration to go up.

\section{Loan And Deposit Portfolio}

In 2001, the volume of bank operations increased in Slovenia, causing total assets to increase by $15.6 \%$. The main reason for it was a great increase of households' deposits, achieving a real growth rate of $26.9 \%$, which is much higher than a growth achieved from 1998 to 2000 (5.8\% to 14.9\%). At the end of 2005, the Slovenian banking system measured the highest growth of total assets in the last five years, which was $20.1 \%$. Deposits in the nonbanking sector continued to decrease, reaching 54.9\%.Loans, on the other hand, continued an increasing trend that started in 2003, reaching 54.5\%. The high level of lending activities that occurred in 2005 exposed the Slovenian banking system to a greater possibility of lending to weaker customers. In 2005 the non-performing loans fell. The sharper decline of those loans has been in foreign banks at 3.07\%; that is, lower than the average for the banking system of $4.79 \%$. The decline of non-performing loans also was measured in domestic banks at $5.32 \%$, which is higher than average.

The banking crisis in Croatia had a great impact on banks, causing the recovery period to start in 1999. The first signs of an improvement in the structure of the banks became visible in 2000. That year, assets were measured at 112.7 billion kuna and showed an increase of $20.5 \%$ from the previous year. In 2001 loan growth was very strong in households and the trend continued into 2002. The Croatian National Bank (CNB) took measures that would prevent strong lending growth and foreign debt, and reduced the pressure on current accounts. Increase in private sector loans was very high and reached to $58.1 \%$ in 2004. The same ratio was $27.5 \%$ in 1996. From 1995 to 2004, private deposits showed an increase from $20.4 \%$ to $60 \%$ of the GDP respectively. At the end of 2005, the structure of deposits was dominated by household deposits at $56.7 \%$, while corporations had $19.6 \%$.

The Macedonian political and security crises in 2001 had an effect on banking activities that year, causing withdrawal of deposits from banks and holding back from making new loans. The situation changed at the end of that year when free euro conversion started and caused an increase in deposits. More than $70 \%$ of deposits received during conversion stayed at banks, which showed a return of confidence in the banking system. The trend of increasing deposits also continued through 2003, exceeding higher levels than one that was registered during euro conversion and bringing great increase in credit activity and showing a stable level through 2004. At the end of 2005 , the increase in loans and deposits were measured. Loans increased by $22.5 \%$ due to an enlarged deposit base, while deposits increased by $19 \%$ from the previous year. Non-performing loans reached the lowest level at $10.87 \%$ at the end of 2005, showing a great decline from 2001 when this ratio was at $33.7 \%$. 
In 2002, Euro conversion in $\boldsymbol{B i H}$ was finished successfully and deposits grew by $25 \%$, which was high, taking also impressive growth in 2001 with $52 \%$. Lending in 2002 grew by 53\%, and the most significant growth was measured in households with $119 \%$. Credit expansion was caused mainly by an increase of deposits, due to conversion, as well as increasing confidence in the banking system. At the end of 2005, in the banking system in $\mathrm{FBiH}$ measured loans increase by 1,100,614 thousands KM, which represented $25 \%$, compared to the previous year. Overall deposits in this entity increased by $1,261,810$ thousands KM, which represented $22.5 \%$. Non-performing loans were $3.1 \%$ in 2005 , which was less than in the previous year when it was $3.8 \%$.

At the beginning of the reforms in Serbia, decline was measured in terms of the domestic loans made to the private sector, especially in 2001 when it represented 6\% of the GDP. In the process of transforming European currencies into the euro, foreign money had to be put into bank accounts and then converted. This process ended up with a conversion of 7.8 billion euros and $75 \%$ of this money was immediately withdrawn from those banks, which once again might prove that there was no confidence in banks at the time. The situation changed at the beginning of 2002 with the liquidation of four major banks. At the end of 2005, overall lending activity increased by 151 billion dinars, which represents $53.1 \%$ compared to the previous year. Overall deposits increased by 171 billion dinars, while decline was measured in foreign exchange deposits as well as dinar deposits. Non-performing loans in total classified assets in 2004 and 2005 stayed at the same level at $23 \%$.

In Montenegro savings increased in 2001 which continued through 2002 with an increase of $200 \%$. At the end of 2005, the loans totaled 375,942 thousand euros, showing a much higher level than in the previous year (281,482 thousand euros) while deposits also measured an increase from 273,195 thousands euros in 2004 to 487,918 thousands euros in December 2005. Savings by citizens measured an incredible growth of $78.4 \%$. There was a decreasing trend in non-performing loans, which dropped from $14.68 \%$ in 2001 to $7.42 \%$ in 2003 , while the situation changed in 2004 to $8.03 \%$ due to problems that Hipotekarna bank experienced that year. In 2005, nonperforming loans increased by $1.93 \%$ in comparison to the previous year.

\section{Profitability Of The Banking Sector And Regulatory Activities}

In 2001, the Slovenian banking system achieved the lowest profit of 1,926 million tolars in the past six years, and the main reason for it was the high losses of one major bank. From 2002 to 2005, profit was growing and reaching its highest level in 2005 at 51,475 million tolars which represented real growth of $11.1 \%$. The ROA in 2005 was $1 \%$ while the ROE was $13.8 \%$. The ROE showed an increase from 2000 when this ratio was measured at $11.4 \%$, while for last five years, the ROA was at the same level-except in 2001, when it was lower and measured at $0.5 \%$. The financial intermediation of Slovenia in 2005 was $94.5 \%$, showing an increase in comparison with 2002 when this ratio was at $79.4 \%$. The minimum capital adequacy ratio in Slovenia is $8 \%$, and all banks satisfy this requirement. If new banks want to operate in this banking market, the minimum capital requirement is 5.092 million euros.

In 1998 there were significant losses measured in Croatia, while in 1999 the banking system earned a profit of 704.2 million kuna. This profit was earned by 41 banks in the amount of 1.2 billion kuna, while 12 banks reported 526.4 million kuna in losses. From 2000 to 2005, profit was growing, and reached its highest level in 2005 at 3,369 million kuna. The ROA in 2005 was $1.70 \%$ while the ROE was 15.6\%. Both ratios showed an increase from 1998, the year of the banking crisis, when those ratios were measured at $-2.8 \%$ and $-16.1 \%$ respectively. Financial intermediation was measured at $108.9 \%$, which was higher than the most of the countries that became a member of the EU in 2004, such as Hungary (82.4\%) and Poland (65.5\%). In Croatia, this ratio increased from 51\% in 1995 as a result of an extensive lending policy. The minimum capital adequacy ratio in Croatia is at $10 \%$ and all banks satisfy this ratio. If new banks want to operate on Croatian territory, the minimum capital requirement is 5.3 million euros.

In 2001, seventeen Macedonian banks made profits and four banks made losses. If we exclude the loss of only one bank, this banking system would show a positive financial result that was at the same level as it was in 2000. From 2002 to 2005, profit was growing, reaching the highest level in 2005 at 1,703 million dinars. At the end of 2005 , ROA was $1.32 \%$, showing a great increase from 2001 when it was measured at $-0.66 \%$, while ROE reached 
$8.11 \%$ from $-3.24 \%$ in 2001 . Financial intermediation from the mid-90s does not show big changes, and it was measured at $57 \%$. This ratio is relatively low, and it shows great catch-up potential for this banking market. The minimum capital adequacy ratio in Macedonia is $8 \%$, and all banks satisfy this ratio. If new banks want to operate in this banking market, the minimum capital requirement is 3.5 million euros.

The banking sector in both entities of $\boldsymbol{B i H}$ measured gains in the new millennium. Lower gains were measured in RS due to a much smaller banking sector. In 2005, gains were measured at 73,700 thousand KM, representing an increase of 17,484 thousand $\mathrm{KM}$ or $31 \%$ from the previous year. The ROA in 2005 was $0.7 \%$, while the ROE was $6.4 \%$. Both ratios show an increase from 2000 when they were measured at $-1.5 \%$ and $-5.8 \%$, respectively. Financial intermediation of $\mathrm{BiH}$ was $72.6 \%$, showing a great increase from 2000 when this ratio was measured at $44.4 \%$. This ratio in 2005 was at the level of average in former Yugoslavian republics. The minimum capital adequacy ratio in $\mathrm{BiH}$ is at $12 \%$, and all banks satisfy this ratio. If a new bank wants to operate in this banking market, the minimum capital requirement is 7.669 million euros as of December 2002. An increase of this ratio is caused by consolidation in this sector and a reduction in the number of banks.

Huge losses were measured in Serbia through the beginning of the new millennium. The situation changed in 2005, when gains were measured at 7,272 million dinars, caused by high spreads and an increase in lending activities. In 2000 ROA was $-6.2 \%$ and it decreased to $-1 \%$ in 2004 while ROE decreased form $78.5 \%$ in 2000 to $5 \%$ in 2004. The financial intermediation was at $38.8 \%$ and represented around one-third of the GDP. The low level of this ratio was caused mainly by the reforms that took place in 2001 and 2002, which included cleaning up the insolvent banks, and at that time the ratio reached 126.8\%. The National Bank of Serbia changed the minimum capital adequacy ratio from $8 \%$ to $12 \%$ in 2005 . In December 2005, no bank had a capital adequacy ratio below $12 \%$. If a new bank wanted to operate in this market, the minimum capital requirement would be 10 million euros.

The banking sector in Montenegro experienced gains in 2002, 2003, and 2005, while losses were obtained in 2001 and 2004. The losses at the end of the 2004 amounted to 1,116 thousands euros, which were mainly caused by the problems that Hipotekarna Banka experienced. If we do not take the losses caused by this bank into account, the situation would be different and the gains would be measured at 6,164 thousands euros. Due to a negative result in 2004 , the ROA ratio was -0.29 while the ROE was $-1.2 \%$. The situation improved at the end of 2005 , when gains were measured at 4,184 thousands euros, and there was also an increase in the ROA to $0.81 \%$ and in the ROE to $4.16 \%$. The financial intermediation of Montenegro is $30.1 \%$, showing a very low level in comparison with the average of $72.2 \%$ for countries that were once part of the SFRY. The minimum capital adequacy ratio in Montenegro is at $8 \%$ and all banks satisfy this ratio. If new banks want to operate on Montenegrian territory, the minimum capital requirement is 5 million euros.

\section{CROSS-COUNTRY COMPARISON ANALYSIS OF BANKING SYSTEMS}

The economic development and reforms of each country during the 1990s can be ranged from shocktherapy type to gradualism. Slovenia used gradualism without crises. Macedonia also used gradualism, which was defensive in the beginning while at the end, activism was increased. Partial shock therapy and defensive gradualism were followed in Croatia, but after 2000, it became more active gradualism, which, as a strategy, speeds up the process in a positive way. In Bosnia and Herzegovina, the strategy that was used was imposed shock therapy with a combination of defensive gradualism. This process tended to slow down reforms in this country. Misguided gradualism was used in Serbia and Montenegro, and it usually appeared in the beginning of transitions in countries with weak institutional sectors. Results showed that the best reforms were in those banking sectors that used partial shock therapy with active gradualism.

In order to do cross-country comparison of the banking system for former Yugoslavian republics, we have to take a look at selected economic indicators in 2005 , which can be seen at Table I.

Some countries performed well in 2005 (real GDP growth of SEE countries was at $4.8 \%$ while this ratio for countries in transition was at 5.3\%). The highest GDP growth rate was measured in Serbia at 5.9\%, while the lowest were at 3.5\% in Macedonia and Croatia. In 2005, the average level of inflation for southeastern European countries 
was at 5.8\%, and former Yugoslavian republics maintained it on a low and stable level, except Serbia, which measured double-digit inflation at $17.7 \%$. Looking at the EBRD transition index, it can be said that all of the countries are classified around 3, which means that "There has been progress in establishment of bank solvency and of a framework for prudential supervision and regulation, while there is significant lending to private enterprises and significant presence of private banks."1

Taking a closer look at each banking system at the end of 2005, we can see differences by examining some of the main indicators, such as concentration of the banking system, ownership structure, non-performing loans, profitability and financial intermediation. The comparison of concentrations for the five largest banks between former Yugoslavian banking systems and with EU countries shows the relatively high concentration of this ratio, ranging between $52 \%$ in Serbia to $81 \%$ in Montenegro. The average level for this ratio in twenty five EU counties was at $40.2 \%$ in 2005, while for new member states in EU this ratio ranged between 50.2\%-98.6\% for the same year. In the most former Yugoslavian republics, concentration is expected to rise due to the existence of small banks that will merge in the near future.

Examining the number of banks in each country, difference in the number of banks was due to country size. The largest banks were majority-foreign-owned in three countries: in both Bosnia and Herzegovina's entities, the main shareholders of the largest banks were from Austria; the same situation was in Serbia; and Croatia's largest bank's major shareholders were from Italy. In Macedonia and Montenegro, the largest banks were in private hands, while in Slovenia, one of the major shareholders in the largest bank was the state, with 35\% in it.

In all countries, the privatization of state-owned banks was one of the most important elements in the rehabilitation of the banking sector. Mainly, privatization can be explained with the entrance of foreign banks, which can be seen by the growing of their shares in capital. The highest foreign shares in capital were in Croatia, with $91.3 \%$, while the lowest were in Slovenia, with $35.1 \%$. The main reason for the lower percentage of foreign shares in Slovenia was due to its strategy to try to keep at least some banks in majority-domestic ownership. In transition counties, shares of domestic ownership in the largest banks are very small, while in all more-developed EU counties, leading banks had at least $80 \%$ shares in domestic hands.

In order to improve asset quality, all countries took measures that gave positive results, and the percent of non-performing loans had declined in 2005 but still was relatively higher than in the EU large banks (this ratio was measured at $2.7 \%$ in 2002). The highest percent of non-performing loans was measured in Serbia at 23\%, while the lowest was in $\mathrm{BiH}$ at $3.1 \%$.

Banks' profitability showed significant improvement during the last couple of years as a result of successful reforms of banking sectors. All countries made profits in 2005. Croatia measured the highest profit of 464 million euros, while the smallest profit was measured in Montenegro at 4.2 million euros. In all countries, banks were well-capitalized with a capital adequacy ratio above minimum that ranged from $8 \%$ in Slovenia, Macedonia and Montenegro and 10\% in Croatia to 12\% in BiH and Serbia. (This ratio in 2003 for EU large banks was at $11.4 \%$, which was above the minimum of $8 \%$ ).

Financial intermediation also showed signs of improvement in the last couple of years, but still in some countries (Serbia, Montenegro and Macedonia), it was still low, which represents a great catching-up potential. BiH is showing a great increase of this ratio, but still it was lower than average for new member states in EU in 2004, which was measured at $78.2 \%$, while in Slovenia this ratio is at a higher level than the average for new member states. Like in new member states in EU, financial intermediation was the highest in the wealthiest country, which was Croatia.

${ }^{1}$ EBDR Transition Report 2003,pg. 17. 


\section{CONCLUSION}

Reforms of the financial sector had influenced expansion of the banking sector over the last ten years. During that period, some banking sectors experienced banking crises, but still the banking sector proved to be one of the most advanced and stable sectors of those countries. One of the results that reforms (privatization of stateowned banks) brought was the entrance of foreign banks during the 1990s. The entrance of foreign banks was the government decision to help bank reconstruction, and the main reason for it was the need for new capital. Their entrance was not easy, keeping in mind the very fragile banking market, low confidence in the banking system and the high requirements (the minimum capital requirement and the capital adequacy that were much higher than in EU countries). The first foreign banks that entered the banking markets of former Yugoslavian countries were banks from the region in order to improve cross-border trade. Beside them, Western European banks (Raiffeisen Bank, Bank Austria HVB, Hypo Alpe Adria Bank, Societe Generale Bank, Uni Credito) entered in most countries, and today they have significant shares, taking into account that most of them are ranked in the top-ten largest banks based on asset size.

The Slovenian banks' expanded abroad to other countries in the region due to advantages such as existing business links, language, and culture. In some countries (Serbia and Montenegro), in the near future, privatization will create more opportunities to foreign banks to enter. Also, it is expected that more mergers and takeovers will take place in order for some banks to survive higher competition as well as tighter regulations on those banking markets. The level of competition, concentration and market shares of foreign banks will increase while the number of banks will further decrease.

Positive correlation is noticeable between privatization and financial intermediation, while negative correlation exists between non-performing loans and financial intermediation. Comparison showed that countries in their early stages of reforms privatized more than $50 \%$ of capital. Also, countries that had mainly-privatized banking sectors had stronger loan growth, due to foreign ownership. A great example of this is Croatia, which started privatization very early, had more than $90 \%$ foreign shares in capital, a low level of non-performing loans and strong loan growth. On the other hand, Macedonian privatization started also very early but shares of foreigners' capital was less than $50 \%$ and measured a higher percentage of non-performing loans. A different situation can be seen in Serbia and Montenegro with very low intermediation at the end of 2005, with foreign ownership around 67\% and higher non-performing loans reaching 23\% in Serbia.

During the next few years, we can expect strong growth on those banking markets. Some central banks, in order to protect stability of the system, issued a warning in response to credit expansion, but still growth of assets and liabilities is expected. More profit is expected to be earned on those markets by looking at the high growth rate. Also, financial intermediation, which is still very low in some countries, will further accelerate growth.

Overall, it can be concluded that former Yugoslavian republics promise very favorable banking development. Preparation for integration with EU will be of significant importance for those countries, which may cause risks in the future.

Table I

Selected Economic Indicators For 2005

\begin{tabular}{|l|c|c|c|c|}
\hline $\begin{array}{l}\text { Former Yugoslavian } \\
\text { Republics }\end{array}$ & Population (million) & GDP growth (\%) & Inflation (\%) & $\begin{array}{c}\text { EBRD Transition } \\
\text { Indicator* }\end{array}$ \\
\hline Bosnia and Herzegovina & 3.8 & 5.0 & 2.8 & 2.59 \\
\hline Croatia & 4.4 & 3.5 & 2.9 & 3.41 \\
\hline Macedonia & 2.0 & 3.5 & 0.0 & 2.96 \\
\hline Montenegro & 0.63 & 4.0 & 1.8 & 2.63 \\
\hline Serbia & 7.57 & 5.9 & 17.7 & 2.63 \\
\hline Slovenia & 2.0 & 3.8 & 2.5 & 3.37 \\
\hline
\end{tabular}

Source: EBRD* Average of nine EBRD transition scores 
Figure I

Concentration Of Five Largest Banks

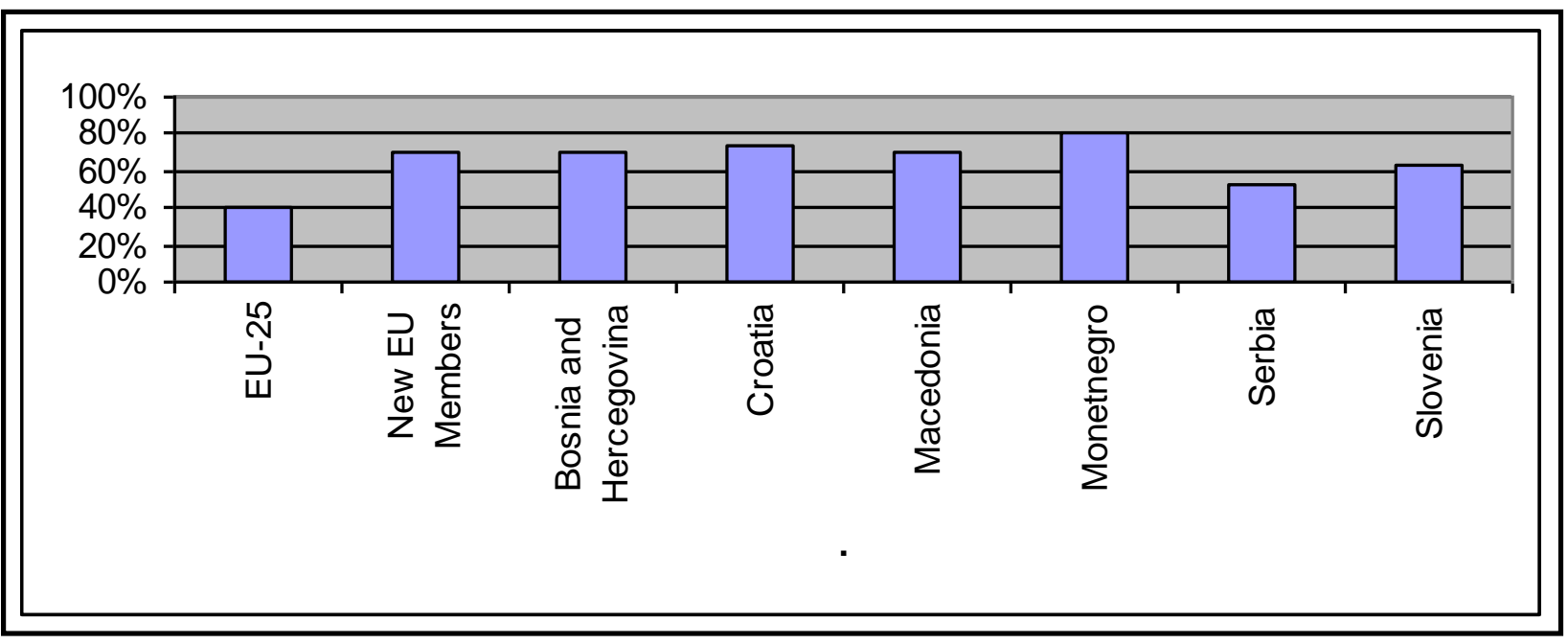

Table II

Bank Ownership Structures In 2005

\begin{tabular}{|l|c|l|c|c|c|}
\hline \multirow{2}{*}{$\begin{array}{c}\text { Former Yugoslavian } \\
\text { Republics }\end{array}$} & $\begin{array}{c}\text { Number } \\
\text { of banks }\end{array}$ & Largest banks & \multicolumn{3}{c|}{ Ownership structure } \\
\cline { 3 - 6 } & 33 & & $\begin{array}{c}\text { Foreign } \\
\text { shares }\end{array}$ & $\begin{array}{c}\text { State } \\
\text { shares }\end{array}$ & $\begin{array}{c}\text { Private } \\
\text { domestic } \\
\text { shares }\end{array}$ \\
\hline Bosnia and Herzegovina & 24 & Raiffeisen Banka BiH dd.Sarajevo & $70.2 \%$ & $\begin{array}{c}16.9 \% \\
\text { n.a. }\end{array}$ & $\begin{array}{c}12.9 \% \\
\text { n.a. }\end{array}$ \\
FBiH & 9 & Hypo Alpe Adria Bank AG & $91.3 \%$ & $5.3 \%$ & $3.4 \%$ \\
\hline Croatia & 34 & Zagrebacka Banka & $49 \%$ & $5 \%$ & $46 \%$ \\
\hline Macedonia & 20 & Komercijalna Banka a.d. Skoplje & $68 \%$ & $13 \%$ & $19 \%$ \\
\hline Montenegro & 10 & Crnogorska Komercijalna Banka & $67 \%$ & $23 \%$ & $10 \%$ \\
\hline Serbia & 40 & Raiffeisenbank a.d. Beograd & $35.1 \%$ & $18.1 \%$ & $46.8 \%$ \\
\hline Slovenia & 19 & NLB & & & 5 \\
\hline Source: ann
\end{tabular}

Source: annual reports from central banks 
Figure II

Non-Performing Loans

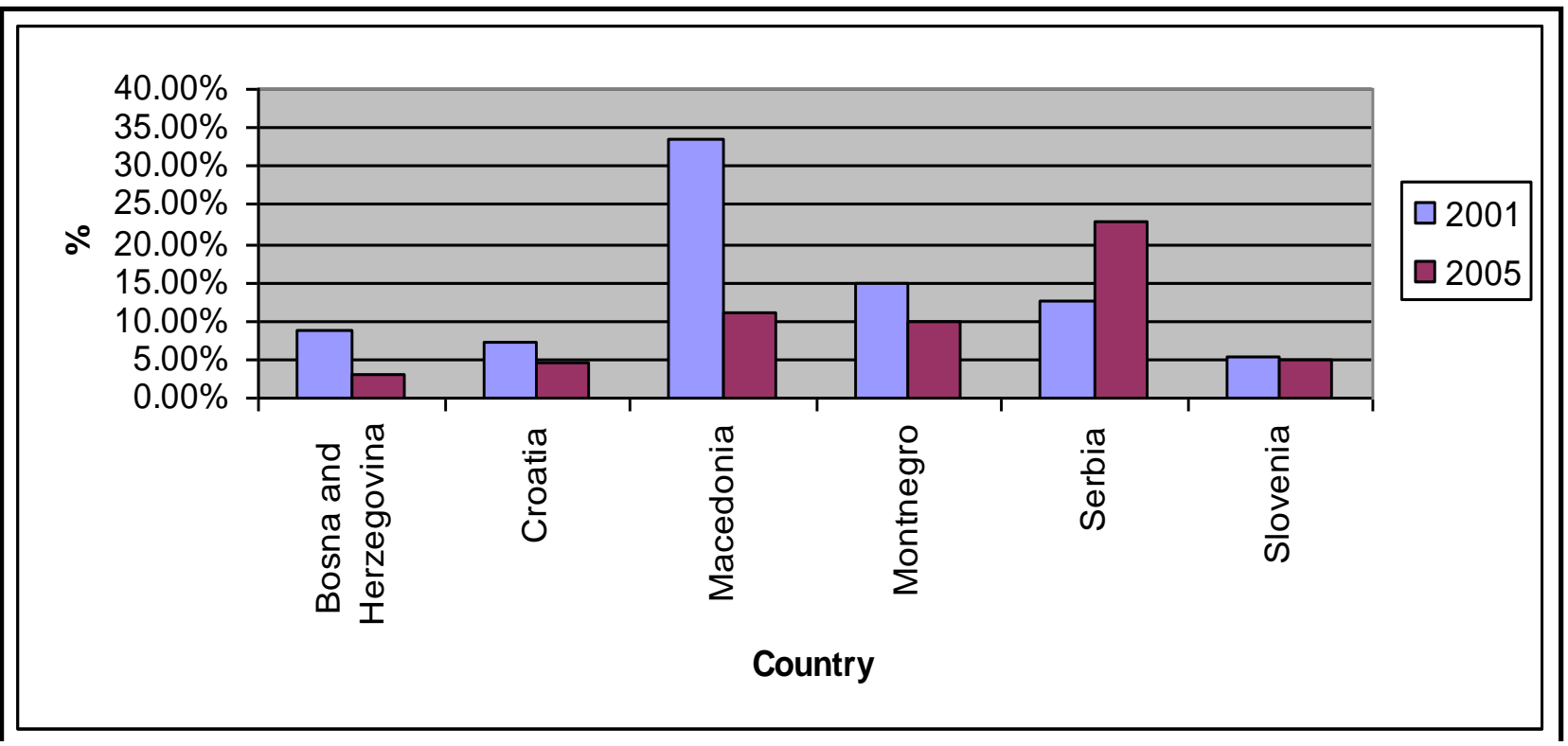

Table III

Selected Banking Indicators In 2005

\begin{tabular}{|l|c|c|c|c|c|c|}
\hline \multirow{2}{*}{$\begin{array}{l}\text { Former Yugoslavian } \\
\text { Republics }\end{array}$} & \multicolumn{2}{|c|}{ Profitability } & \multirow{2}{*}{$\begin{array}{c}\text { Profit/losses } \\
\text { (million euros) }\end{array}$} & $\begin{array}{c}\text { Minimum capital } \\
\text { adequacy ratio }\end{array}$ & $\begin{array}{c}\text { Minimum Capital } \\
\text { requirement } \\
\text { (million euros) }\end{array}$ & $\begin{array}{c}\text { Financial } \\
\text { intermedi } \\
\text { ation }\end{array}$ \\
\cline { 2 - 3 } & ROA & ROE & & $12 \%$ & 7.669 & $72.6 \%$ \\
\hline Bosnia and Herzegovina & $0.7 \%$ & $6.4 \%$ & 38 & $10 \%$ & 5.3 & $108.9 \%$ \\
\hline Croatia & $1.7 \%$ & $15.6 \%$ & 464 & $8 \%$ & 3.5 & $57 \%$ \\
\hline Macedonia & $1.32 \%$ & $8.11 \%$ & 28 & $8 \%$ & 5.0 & $30.1 \%$ \\
\hline Montenegro & $0.81 \%$ & $4.16 \%$ & 4.2 & $12 \%$ & 10.0 & $38.8 \%$ \\
\hline Serbia & $-1 \% *$ & $-5 \% *$ & 88 & $8 \%$ & 5.09 & $94.5 \%$ \\
\hline Slovenia & $1 \%$ & $13.8 \%$ & 215 & & & \\
\hline
\end{tabular}

Source: annual reports from central banks

* Data on 2004

\section{AUTHOR INFORMATION}

Jelena Radzic is an economist with a master degree in International Economics and Finance. She has worked as analyst for the Central Bank of Montenegro.

Ayşe Yüce is professor of Finance. She has written many articles and books about international financial markets. She currently works as the chair of Finance Department at Ted Rogers School of Management.

\section{REFERENCES}

1. Bank of Slovenia: Annual reports, various issues, Ljubljana.

2. Belgrade Centre for European Integration (BeCEI): European Balkan Observer, various issues.

3. Bonin J., 2004. Banking in Balkans: the structure of banking sector in Southeast Europe. Economic systems, 28, 141-153. 
4. Bonin J., Hasan I., Wachtel P., 2005. Bank performance, efficiency and ownership in transition countries. Journal of Banking and Finance, 29, 31-53.

5. Central Bank of Bosnia and Herzegovina: Annual reports, various issues, Sarajevo.

6. Central Bank of Montenegro: Annual Reports, various issues, Podgorica.

7. Croatian National Bank: Annual reports, various issues, Zagreb.

8. Dvorsky S., 2004. Central Bank Independence in Southeast Europe with a View to Future EU Accession. Oesterreichische Nationalbank, European Affairs and International Financial Organization Division.

9. European Bank for Reconstruction and Development (EBRD): Transition reports, various issues.

10. Gomel G., 2002. Banking and Financial Sector in Transition Countries and Convergence toward European Integration. Banca d'Italia, International relations.

11. Hasan I., Marton K., 2002. Development and efficiency of the banking sector in a transitional economy: Hungarian experience. Journal of Banking and Finance, 27, 2249-2271.

12. Havrylchyk O., 2005. Efficiency of Polish banking industry: Foreign versus domestic banks. Journal of Banking and Finance, article in press.

13. Havrylchyk O., Jurzyk E., 2006. Profitability of foreign and domestic banks in Central and Eastern Europe: does the mod of entry matter? Journal of Banking and Finance, article in press.

14. Kraft, E., 2004. Banking Reform in South East Europe: Accomplishment and Challenges. Paper Presented at the OeNB Conference on European Economic Integration, Nov.28-30, 2004 Vienna.

15. National Bank of Serbia: Annual Reports, various issues, Beograd.

16. National Bank of the Republic of Macedonia: Annual Reports, various issues, Skopje.

17. Wisniwski S., 2003. Bankers' Perspective-Dynamic Banking in a Changing Market. 2003 KfW Southeast Europe Financial Sector Development Symposium, Nov. 13-14, 2003, Berlin.

\section{NOTES}


NOTES 